\title{
Sustainability of Local Empowerment and Environmental Management Project in Enugu State
}

\author{
Onah Roseline C. ${ }^{1}$ Ayogu Gabriel I. ${ }^{2}$ Agboeze Matthias U. ${ }^{3}$ \\ ${ }^{1,2}$ Department of Public Administration and Local Government \\ ${ }^{3}$ Department of Adult Education and Extra-Mural Studies University of Nigeria, Nsukka
}

\begin{abstract}
Disused and abandoned completed projects of LEEMP are common features of many communities in Enugu state, Nigeria. This situation prevails against the background of gross inadequacy of basic infrastructure and social amenities in rural communities in the country at large and the state in particular. Against this backdrop, this study attempts to find out the factors that are responsible for the non-sustainability of LEEMP projects, with particular focus on Enugu state. Data were gathered through both primary and secondary sources. Findings show that the non-sustainability of LEEMP projects in Enugu State was primarily as a result of a number of factors namely; poor follow up funding for maintenance, local politics/conflicts, improper location of LEEMP projects and lack of political will by indigenes. A number of recommendations are therefore made which if adopted, will significantly reduce if not totally eliminate those factors that impede project sustainability in the state.
\end{abstract}

Key words: Local Empowerment and Environmental Management Project (LEEMP); Project Sustainability; Community Driven Development (CDD).

\section{Introduction}

Poverty and deprivation in the rural areas have been serious issues in Nigeria. Almost all the rural communities in the country are underdeveloped. Incidentally, Nigeria has more rural than urban communities. This implies that a greater part of Nigeria is underdeveloped. Apart from the fact that infrastructural facilities such as roads, electricity, good schools and health services are not available, the quality of life of rural dwellers is, in most cases, below acceptable human standards. This ugly scenario has led to a large drift of youths from the rural to urban areas which are better endowed with social amenities. This migration to the urban areas leads to other problems which make the cities unsafe. These include kidnapping, armed robbery, religious conflicts among others. These and their nefarious effects have brought international opprobrium upon Nigeria among the comity of nations.

Various governments have made efforts towards addressing the poverty and deprivations of rural dwellers in Nigeria. Governments have adopted a number of policies, programmes and projects aimed at alleviating the problems of the rural people. These include the Agricultural Development Projects (ADPs), the River Basin Development Authorities (RBDA), National Agricultural Land Development Authorities (NALDA) and the Operation Feed the Nation (OFN). There were also the Directorate of Food, Roads and Rural Infrastructure (DFRRI); the Better Life for Rural Women programme, health programmes like the Primary Health Care (PHC), the Guinea Worm Eradication Programme and the Drug Revolving schemes of many state governments. The Education sector equally received attention in the form of Nomadic Education Scheme, Unity Schools and the Gifted Children School project. In the area of small scale credit schemes, there were the various banking programmes, the Sectorial Allocation Schemes, the Peoples' Bank, the Nigerian Agricultural Cooperative, the Rural Development Bank, the Community Bank, the National Economic Advancement Programme to mention a few (Onakuse and Eamon, 2007). With this litany of schemes and resources invested therein, the lives of the rural people have not been appreciably touched as the schemes suffered sustainability challenges. Most of them have been long abandoned (Eze, 2007).

Confronted with the non-sustainability and failures of rural poverty reduction schemes, the Federal Government of Nigeria in partnership with the World Bank designed the Local Empowerment and Environmental Management Project (LEEMP) to address the problems of unsustainable management of the environment, poor utilization of non replenishable natural resources, extreme rural and urban poverty; and highly centralized governance (FSPU, 2004). Sequel to the above, the Federal Government of Nigeria in collaboration with Enugu State Government sought and obtained financial assistance from the International Development Association (IDA) and the Global Environmental Facility (GEF) to combat poverty through community empowerment and sustainable management of the environment in the State.

With this arrangement, many projects were executed in Enugu state under LEEMP. These projects were completed on schedule and the communities in Enugu State heaved sigh of relief from traveling far distances to access education (primary and secondary), health facilities and electricity. But later visits to these 
once fortunate communities showed that the bad old days were back or gradually coming back as water taps dried and were over grown with bushes; health facilities were desolate, housing mostly reptiles; electric cables and poles collapsed just after five years of operation (2004-2009) and three years after replacement with the Community and Social Development Project, (CSDP).

It is against this backdrop that this paper examines whether follow-up funding for maintenance negatively affected the sustainability of LEEMP projects in Enugu State. The work also ascertains if local politics and conflicts in communities had any significant effect on the sustainability of LEEMP projects in Enugu State. It also explores whether the location of projects affected the sustainability and the effect of political will (or lack of it) on the sustainability of LEEMP projects in Enugu State.

\section{Project sustainability}

\section{Conceptual Clarification}

Sustainability is the ability of a project to maintain its operations, services and benefits during its projected life time. The International Federation for Agricultural Development (IFAD) (2007j) maintains that sustainability entails ensuring that the institutions supported through projects and benefits realized are maintained and continued after the end of the project. Measurement of sustainability entails further, determining whether the results of the project will be sustained in the medium or even longer term without continued assistance (Khan, 2000).

Project sustainability is measured as the percentage of projects initiated- goods and services that are still being delivered and maintained after five years of termination of implementation of the projects; the continuation of local action stimulated by the project and generation of successor and initiatives as a result of project built (Diana and Sattererthwaite, 2007). In its contribution, the European Education Commission and Culture (2006), maintain that a project can be considered as sustainable if relevant activities are pursued and output maintained or developed after the end of the European Union (EU) (development partner) funding.

Within the context of this paper, project sustainability is considered as the ability of a project to maintain its operations and services after the completion and handover of the project to the community, until its projected life time.

\section{Theoretical Framework}

The World Bank Community Driven Development (CDD) Approach has been adopted as the theoretical underpinning for this study. Community-Driven Development (CDD) is an approach that gives control of development decisions and resources to community groups. Under this approach, poor communities receive funds, decide on their use, plan and execute the chosen local projects, and monitor the provision of services that result there from (IDA, 2009). Community-Driven Development (CDD) treats poor people and their institutions as assets and partners in development process. CDD holds the view that given clear rules of the game, access to information and appropriate support, poor men and women can effectively organize the provision of goods and services that meet their immediate priorities (Alkire et al, 2001).

The disappointing results of the "top-down" approaches that were common before the 1980s, especially in rural development programmes, might be improved upon, some people believe, by engaging the communities themselves in planning and managing local service delivery.

Fundamental to CDD interventions is the concept of empowerment. Empowerment of the poor is expected to increase their assets and capabilities to participate in and hold accountable institutions that affect their lives (Operation and Evaluation Department, World Bank, 2003). CDD regards the empowerment of the poor as central to the fight against poverty.

Community-Driven Development of the World Bank puts communities in charge of their own development in order to harness their considerable potential and social capital to improve the livelihood of the people. The stimulus for a CDD effort can come from inside a community or outside, that is, an outside individual, nongovernmental organization (NGO), government or donors (Sara and Katz, 1997).

The CDD approach is underpinned by five basic assumptions (Operations Evaluation Department, World Bank, 2003). First, local communities are more aware of their problems and needs than the government or an outside expert and do a better job of allocating resources, enforcing rules, and targeting the poor. Second, a tangible benefit flow can be created. Third, a representative group from the community that is capable of implementing and managing resources can be identified. Fourth, control over resources is devolved to the local level. The critical fifth assumption is the availability of more information at the community level, and the greater accountability of the representative group selected from within the community to the local people (Adato et al, 1999).

The fact that CDD places the community at the center of the development process makes it an appropriate model to anchor the search for project sustainability. The CDD approach if adopted by LEEMP will to a very large measure ameliorate; if not totally eliminate such challenges as lack of funds. It has an in-built 
mechanism for community participation in fund raising and management. Making communities in charge of their own project which is a key tenet of CDD will equally generate interest, promote political will and enhance accountability, factors which have been identified as impediments to the sustainability of LEEMP projects in Enugu State.

\section{Objectives and Operational Procedure of LEEMP}

LEEMP is a poverty reduction strategy through which the Federal and State Governments of Nigeria had obtained credit assistance from the International Development Association (IDA) and the World Bank Group, Global Environmental Facility (GEF) for the execution of priority projects that impact directly on the lives of the rural population. It aims at enhancing the standard of living of the dwellers by empowering communities and local governments to collaboratively plan design and implement environmentally sustainable and socially inclusive development priorities (LEEMP, 2005).

The Local Empowerment and Environmental Management Project is a five-year partnership between the Government of Nigeria and the World Bank. It is a recent initiative in bettering the lot of mankind by empowering people to improve themselves. It is designed to address the problems of: unsustainable management of the environment; poor utilization of non -replenishable natural resources; extreme rural and urban poverty; and highly centralized government. (FGN, 2004). To adequately address the above stated problems, LEEMP seeks to improve the welfare and living conditions of many poor and vulnerable rural and urban dwellers by transferring resources directly to community members and giving them the authority to the resources to address their chosen development needs.

The purpose of LEEMP can be summarized into two broad objectives namely; to strengthen institutional framework at Federal, State and Local Government levels to support environmentally sustainable and socially inclusive development and to support beneficiary communities to plan, co-finance, implement, operate and maintain environmentally sustainable and socially inclusive multi-sector micro-projects LEEMP (2005:23). Under LEEMP, the local government is not required to make any mandatory financial contribution. However, voluntary contribution in cash or kind is acceptable and often made (Papka, 2005). For instance, office space for project staff is provided free; the wages of local government staff deployed to project sites are paid by the council, and some other forms of logistics support provided. The project has a complicated arrangement for mandatory financial contribution at the community level. Micro-projects relating to infrastructure and social services require a contribution of 20 percent of total cost, at least half of which must be in cash (FPSU, 2002). Environmental/natural resources-related activities require a contribution of 10 percent of cost in cash or kind. But individuals benefiting directly from such activities for example, a person whose property or land is close to an environmental treat, is required to contribute 2 out of the 10 percent (LEEMP, 2009).

LEEMP releases funds to communities in three tranches. The fund is released at the rate of 20,50 , and 30 percent respectively. The release of funds in tranches is informed by the need to ensure a judicious use of funds. The first tranche is to enable implementation to commence and this first tranche is for a learning period. The second tranche is released based on confirmed progress of work through monitoring and evaluation reports, inspection visits and submission of necessary receipts and other documents. The third tranche is released to enable the community complete the micro-projects, having judiciously expended the second tranche. Both learning process and accountability are built into the tranche approach (IDA, 2001).

\section{Challenges to the Local Empowerment and Environmental Management Project (LEEMP) in Enugu State}

Previous studies reveal a number of problems/challenges which impeded the implementation of LEEMP projects in some communities in Enugu State and the nation at large. Some of these are discussed below.

The Community Project Management Committee (CPMC) Members, a group of people elected/selected by the communities to handle the implementation of the LEEMP project(s) in their communities exhibited lack of transparency leading to the call for their change. Whenever this happened, no doubt, the project suffered delays and possible sabotage by the people being replaced. Ugbene - Ajima electricity project in Uzo-Uwani Local Government Area suffered this problem (Enugu LEEMP, 2009). In some places, many CPMC members did not attend meetings if they were not sure of drinks or food. Some members asked for allowances when they came for meeting as M.A.C. Ozioko, CPMC chairman Obige Obukpa in Nsukka L.G.A. complained.

Lack of funds also led to some projects remaining uncompleted or being completed later than the project timeframe. The lack of funds was as a result of poor costing or failure by community to raise the funds to pay their 10 percent cash counterpart. This resulted from the fact that some members of the communities initially doubted the authenticity of LEEMP and therefore, refused to contribute money for the projects. 
Some of the contractors were dubious and abandoned their contracts. This happened at Umuagu Inyi, Oji-River Local Government Area water borehole project. They also manipulated the CPMC members in some communities who were largely illiterates in the course of the projects to purchase and install inferior materials (Ugwoke, 2008:10).

It was also found out that some educated and influential men in the communities hijacked the project(s) and manipulated same to suite their interests, while the less influential majority were left out of the decision making processes. This again engendered lack of interest by those that were left out. (Owoh, 2008:8). He further explained that political affiliations created power centers in the villages/ communities. Decisions related to the management of projects were in most cases influenced by these power centers, making it difficult for other villages to voice their needs and opinions. This hindered monitoring, as those excluded were not willing to support or participate in the exercise.

Other challenges to the projects included poor data gathering and information management by community members because of illiteracy, poor attitude, inadequate logistics and difficult terrain of some communities (Eze, 2007).

\section{How to ensure the Sustainability of Development Projects}

IFAD (2010:12) identifies a number of measures necessary to achieve project sustainability. To this effect, it argues that development models leading to sustainability must be responsive to the operating environment while key elements of a sustainability strategy should be introduced early in the project design phases. Special attention should equally be devoted to improved monitoring and evaluation systems that facilitate and document progress towards sustainability. Very importantly too, in the interest of sustainability, projects should prioritize the involvement of existing community assets and structures over the establishment of new institutions.

The Handbook on Sustainability (2006) enumerated the measures to take care of sustainability challenges and enhance the sustainability of development projects. The crucial measures are as presented below.

1. Improving the Quality of Project Design in Meeting Social Needs: - The quality of the project design is the first sustainability factor from a time logic point of view. A project should be designed to meet specific needs and constraints in the partner country namely health, illiteracy, language, terrain, poverty etc. Projects that match the real need of people are more likely to be sustainable.

2. Involvement of Consortium Members/Sense of Ownership and Motivation: The involvement of consortium members is crucial in a bottom-up process which usually adopted Tempus Projects dictum, implying that "commitment is necessary, enthusiasm is not sufficient". This means that the partners share common interest in the project and respect one other's values. It can sometimes counter balance lack of national support. Shared involvement can also favour efficient management and the capacity to find alternative resources and support.

3. Effective Management and Leadership: This factor relates to the project leaders and to their professional motivations, skills and ability to manage the whole project. Effective management favours the involvement of partners, fund raising, and the ability to anticipate sustainability. For instance, the project manager can anticipate language problems and implement quality procedures, and organize an active dissemination of the project results to potential financiers or donors. It is also favoured by a clear distribution of rights and responsibilities, which develop confidence amongst the partners (Teodoro and Royos Co, 2009).

4. Active Participation of the Direct Target Groups: Beneficiaries' help is obviously useful, particularly in villages where resources are insufficient. This participation can be in kind if not in cash. Moreover, the target groups can be actively involved during implementation of the project for the purpose of building a sense of ownership, recruiting new participants, and so forth.

5. Developing Capacity for Securing Adequate Resources for Continuation: A sustainable project should ensure appropriate resources in order to be maintained. These include financial resources (internal and external to the communities) as well as human resources and material equipment. The project managers should anticipate the end of the development partner funding sooner rather than later by seeking alternative sources of finance or making project self-sufficient.

6 Institutional Support: A project can be supported by institutional and organizational leaders (central authorities). Official authorities inside the institution are one of the key counterparts since they countersign the project proposal. Top management support is crucial for operational managers in supporting the project's activities and processes.

7 Support from National Authorities: National support refers to the national state institutions through the competent ministries, political and administrative means. This support may be in the form of financial resources as well as communication. Its role and importance depend largely on the organizational scheme of the countries concerned. Ministries' support for accreditation is a key factor to community development 
projects and can be anticipated. Making provision for accreditation as early as the design phase is a form of best practice.

Measures needed to ensure sustainability of development projects could equally include providing development projects that meet the felt needs of the community members. This therefore, calls for the need to carry out needs assessment in communities before the provision of development projects. Appointing men and women of honor and integrity to leadership positions also ensures project sustainability. Such honest leaders will ensure that money contributed for execution of development projects are judiciously used for that purpose (Ukpongson et al, 2011). It will also encourage community members to pay their contributions towards development projects, since they are assured that such money will be properly accounted for.

As rightly pointed out by Olukotun (2008), when communities are involved in project initiation and implementation, there is the assurance of sustainability subject to some conditions, unlike when they have no idea about the project or when it is imposed them. Communities have to be sensitized to make their efforts/resources available especially in form of community counterpart funding a priority and pay on time too. This will help to ensure prompt disbursement of project funds (Ibeawuchi \& Nwachukwu, 2010). Above all, local government councils should be admonished to assist the poor communities in their localities in paying their counterpart funds.

\section{Hypotheses}

The following hypotheses were formulated to guide the study:

1. Follow-up funding for maintenance had no significant effect on the sustainability of LEEMP projects in Enugu State.

2. Local politics and conflicts had no significant effect on the sustainability of LEEMP projects in Enugu State.

3. Site/location of LEEMP projects in Enugu State did not significantly impinge on their sustainability.

4. Lack of political will by the indigenes did not constitute significant impediment to the sustainability of LEEMP projects in Enugu State.

\section{Methodology}

Data were collected from both primary and secondary sources. Primary data were gathered through questionnaires which were administered directly to respondents. Secondary data were gathered from relevant documents from the Enugu State office of CSDP (LEEMP), Enugu, including annual reports, baseline survey reports, LEEMP magazines and statements of accounts. The researchers also observed the projects directly as they visited some of the project sites.

The population of the study was made up of the 491,250 people who were residents of the LEEMP communities in the ninety-four (94) communities and nine (9) local governments where the project intervened in Enugu State, as well as 45 LEEMP officials in the state. Three local governments were selected from each of the three (3) senatorial zones of the state-Enugu North, Enugu West and Enugu East.

A sample size of 440 was drawn from the total population comprising 400 of the residents of the LEEMP communities and 40 officials of the (CSDP), Enugu. In order to determine how many will be drawn from each category that make up the population of the study, the researcher adopted Yaro Yameni formula which is given thus.

\section{$N$ \\ $\mathrm{n}=\overline{1+N\left(e^{2}\right)}$}

Where $\mathrm{n}=$ sample size; $\mathrm{N}=$ population of the study; $\mathrm{e}=$ margin of error and $1=$ constant (while the margin error (e) is taken to be at $5 \%$ or 0.05 ).

In drawing the sample, the researchers adopted random and purposive sampling techniques. Five (5) local government areas were sampled out of the nine (9) LGAs of intervention in Enugu state. This comprised of two (2) LGAs each from Enugu North and East Senatorial Zones that have six (6) LGAs each and one (1) LGA from the Enugu West Senatorial zone that has five (5) LGAs.

Through a purposive sampling technique, five (5) communities were selected from the LGAs based on the type of project(s) executed, to cover all the sectors LEEMP participated in Enugu State. The projects comprised electricity, water borehole, health centers, roads/ converts and education/school projects. In the course of distributing the instruments to the communities, all the nine (9) CPMC members were chosen while the purposive sampling technique was used to select (7) personalities to represent opinion leaders in the communities such as, traditional rulers, town union leaders, religious bodies as well as youth and women organizations considered to have vital information on the LEEMP project (s) in their communities.

Percentages, tables and frequencies were employed in the study to facilitate the interpretation of the data collected. Chi-Square test $\left(\mathrm{X}^{2}\right)$ was used to determine the result of the relevant hypotheses. The level of significance of the chi-square was set at a $0.05 \%$. The null hypotheses (Ho) was accepted when the calculated 
value was less than or equal to tabulated value of the chi-square but rejected when the calculated value of the chi-square $\left(\mathrm{X}^{2}\right)$ was greater than the tabulated value.

\section{Findings}

\section{Findings and Discussion}

The study found out that during the LEEMP First Phase Intervention (2004-2009), vital sectors of the economy in Enugu State were reasonably funded. A total of 127 micro-projects were implemented by the communities as at December 2007 costing over N420, 609, 320, 66 (see table 1).

Table 1: The sector disbursement for micro-projects implementation by communities from July 2004 to Source: Enugu LEEMP News (2008), p14

\section{December 2007}

\begin{tabular}{|l|l|l|l|l|l|l|l|}
\hline $\begin{array}{l}\text { S/ } \\
\mathrm{N}\end{array}$ & Sector & $\begin{array}{l}\text { No. of } \\
\text { Micro } \\
\text { projec } \\
\text { ts }\end{array}$ & $\begin{array}{l}\text { Total project cost } \\
\mathrm{N})\end{array}$ & $\begin{array}{l}\text { Expected LEEMP } \\
\text { (IDA) } \\
\text { Contribution (N) }\end{array}$ & $\begin{array}{c}\text { Expected } \\
\text { community } \\
\text { Contribution } \\
(\mathrm{N})\end{array}$ & $\begin{array}{c}\text { Actual } \\
\text { community } \\
\text { fontribution (N) }\end{array}$ & $\begin{array}{l}\text { Actual LEEMP } \\
\text { (IDA) } \\
\text { Contribution (N) }\end{array}$ \\
\hline 1 & Water & 28 & $161,139,947.21$ & $138,068,367.28$ & $23,643,425.35$ & $12,521,736.50$ & $101,411,782.65$ \\
\hline 2 & Electricity & 35 & $217,652,940.55$ & $181,562.080 .06$ & $34,262,384.63$ & $15,015,062.30$ & $150,807,635.71$ \\
\hline 3 & Education & 18 & $67,441,232.13$ & $60,697,124.99$ & $6,744,106.11$ & $3,674,928.50$ & $39,516,049.26$ \\
\hline 4 & Health & 15 & $74,505,135.30$ & $67,066,928.10$ & $7,446,013.53$ & $4,494,140.00$ & $49,798,369.85$ \\
\hline 5 & $\begin{array}{l}\text { Roads/ } \\
\text { Bridges/ }\end{array}$ & 23 & $112,349,025.74$ & $3,161,520.10$ & $4,531,369.38$ & $9,272,093.00$ & $75,878,800.79$ \\
\hline 6 & $\begin{array}{l}\text { Socio- } \\
\text { Economic }\end{array}$ & 3 & $11,839,562.50$ & $10,6555,606.20$ & $1,183,956.25$ & 839.770 .00 & $3,196,682.40$ \\
\hline & Total & 127 & $644,927,870.43$ & $466,211,626.73$ & $178,716,243$. & $45,817,730.3$ & $420,609,320.6$ \\
\hline
\end{tabular}

Table 1 indicates clearly that a huge amount of funds $(\mathrm{N} 466,427,050.9)$ were actually disbursed for the execution of 127 projects variously located in the local governments under study. Table 2 is even more explicit as it shows how much was disbursed to each sector in the local governments of interest.

Table 2: Sector Disbursement of Enugu State LEEMP Interventions to Participating

\section{LGAs}

\begin{tabular}{|c|c|c|c|c|c|c|c|c|c|c|}
\hline & & LGAs & & & & & & & & \\
\hline $\mathrm{S} /$ & Sector & Awgu & Ezeagu & Oji River & \begin{tabular}{|l} 
Nkanu \\
East
\end{tabular} & $\begin{array}{l}\text { Nkanu- } \\
\text { West }\end{array}$ & Isi-Uzo & $\begin{array}{l}\text { Igbo-Eze } \\
\text { North }\end{array}$ & Nsukka & Uzo-Uwani \\
\hline 1 & Water & $\begin{array}{l}2,390,273.5 \\
0\end{array}$ & $\begin{array}{l}17,305,80 \\
4.80\end{array}$ & $\begin{array}{l}6,328,647 \\
45\end{array}$ & & $\begin{array}{l}18,458,65 \\
5.80\end{array}$ & & \begin{tabular}{|l}
$24,240,00$ \\
0.00
\end{tabular} & $\begin{array}{l}26,326,00 \\
0.00\end{array}$ & $\begin{array}{l}6,362,401.1 \\
0\end{array}$ \\
\hline 2 & \begin{tabular}{|l} 
Electrific \\
ation \\
\end{tabular} & & $\begin{array}{l}30,907,45 \\
3.24 \\
\end{array}$ & $\begin{array}{l}18,265,91 \\
9 \\
9\end{array}$ & $\begin{array}{l}24,333,84 \\
5.85 \\
\end{array}$ & \begin{tabular}{|l|}
$17,485,01$ \\
9.90 \\
\end{tabular} & $\begin{array}{l}16,638,31 \\
6.59 \\
\end{array}$ & $\begin{array}{l}23,023,16 \\
0.22 \\
\end{array}$ & & \begin{tabular}{|l|l|}
$20,153,92$ \\
0.9 \\
\end{tabular} \\
\hline 3 & Education & $\begin{array}{l}16,034,813 . \\
52\end{array}$ & $\begin{array}{l}\begin{array}{l}315,495.0 \\
0\end{array} \\
0\end{array}$ & $\begin{array}{l}1,430865 . \\
00\end{array}$ & $\begin{array}{l}10,081,84 \\
9.66\end{array}$ & $\begin{array}{l}6,771,786 . \\
40\end{array}$ & $\begin{array}{l}2,778,250 . \\
00\end{array}$ & $\begin{array}{l}1,781,095 . \\
68\end{array}$ & $\mid \begin{array}{l}321,894.0 \\
0\end{array}$ & - \\
\hline 4 & Health & $\begin{array}{l}7,756,240.5 \\
0\end{array}$ & $\begin{array}{l}3,329,834 . \\
25\end{array}$ & $\begin{array}{l}407,331.9 \\
0\end{array}$ & $\begin{array}{l}4,584,254 . \\
40\end{array}$ & $\begin{array}{l}10,114,99 \\
9.45\end{array}$ & $\begin{array}{l}4,584,255 . \\
00\end{array}$ & $\begin{array}{l}2,772,000 . \\
00\end{array}$ & $\begin{array}{l}\begin{array}{l}5,374,580 \\
15\end{array} \\
\end{array}$ & $\begin{array}{l}10,874,87 \\
3.7\end{array}$ \\
\hline 5 & $\begin{array}{l}\text { Roads \& } \\
\text { Bridges }\end{array}$ & $\begin{array}{l}12,073,113 . \\
75\end{array}$ & $\begin{array}{l}5,034,261 . \\
60\end{array}$ & $\begin{array}{l}4,541,695 \\
.80\end{array}$ & $\begin{array}{l}6,300,000 . \\
00\end{array}$ & 11.569 .00 & $\begin{array}{l}13,196,97 \\
5.04\end{array}$ & & $\begin{array}{l}10,845,74 \\
5.65\end{array}$ & $\begin{array}{l}12,317,35 \\
5.9\end{array}$ \\
\hline 6 & $\begin{array}{l}\text { Socio- } \\
\text { economic }\end{array}$ & & & $\begin{array}{l}1,139,308 \\
.90\end{array}$ & & {$\left[\begin{array}{l}934,402.5 \\
0\end{array}\right.$} & & & $\begin{array}{l}1,122,971 . \\
00\end{array}$ & - \\
\hline & Total & $\begin{array}{l}38,254,491 . \\
2\end{array}$ & $\begin{array}{l}56,892,84 \\
8.89\end{array}$ & $\begin{array}{l}32,113,76 \\
8.05\end{array}$ & $\begin{array}{l}45,299,94 \\
9.91\end{array}$ & $\begin{array}{l}65,334,46 \\
7.55\end{array}$ & $\begin{array}{l}37,197,79 \\
6.63\end{array}$ & $\begin{array}{l}51,816,25 \\
5.90\end{array}$ & $\begin{array}{l}43,991,19 \\
0.80\end{array}$ & $\begin{array}{l}49,708,55 \\
1.6\end{array}$ \\
\hline
\end{tabular}

Source: Enugu LEEMP News (2008), p14.

These sector disbursements were fairly distributed among the selected LGAs under study. As can be observed, none of the local governments got less than N32, 113,766 for micro-

Project implementation.

With the above prodigies of LEEMP in Enugu State communities, one would think that the communities would be free from the problems orchestrated by poor rural infrastructural development. But within few years of the completion of these projects, the rural communities began to trek distances to access drinking water, health care services, and return to darkness as they began to witness the folding up of erstwhile small scale businesses opened when the communities were provided with electricity.

Field observation at some of the communities' projects indicates that the projects have become ghosts of their former selves. These resulted from the inability of the communities to sustain these projects as the LEEMP (CSDP) has turned its searchlight to other communities (LGAs) that "envied" the "lucky" ones that 
benefited from 2004-2009 arrangements. Table 3 contains some of the LEEMP projects that have been so neglected.

Table 3: Selected communities where LEEMP Projects have suffered Neglect.

\begin{tabular}{|c|c|c|c|}
\hline LGAs & Communities & Projects & Problems \\
\hline Nanu West & $\begin{array}{ll}\text { 1. } & \text { Mbogodo } \\
\text { 2. } & \text { Obuno Uno } \\
\text { 3. } & \\
\text { 4. } & \text { ObinaguNdiuno }\end{array}$ & $\begin{array}{l}\text { Health centre } \\
\text { Electricity } \\
\\
\text { water borehole } \\
\text { Electricity }\end{array}$ & $\begin{array}{l}\text { Lack of drugs. } \\
\text { Bushen stolen few days after handover. } \\
\text { Over-grown with grasses. Fault not } \\
\text { ascertained. } \\
\text { Oil tank destroyed. }\end{array}$ \\
\hline Ezeagu & $\begin{array}{ll}\text { 1. } & \text { UmumbaNdiagu } \\
\text { 2. } & \text { EzemaOlo } \\
\text { 3. } & \text { Obuho } \\
\text { 4. } & \text { UmudimImeziOwa } \\
\end{array}$ & $\begin{array}{l}\text { Electricity. } \\
\text { water borehole } \\
\text { Healthcentre } \\
\text { Electricity. }\end{array}$ & $\begin{array}{l}\text { Transformer faulty. } \\
\text { Submassible pumps faulty. } \\
\text { Lack of essential drugs } \\
\text { Transformer faulty. } \\
\end{array}$ \\
\hline Uzo- Uwani & $\begin{array}{ll}\text { 1. } & \text { Akpugo- Ezedike } \\
\text { 2. } & \text { Adaba } \\
\text { 3. } & \text { Nrobo } \\
\text { 4. } & \text { UgbeneAjima } \\
\text { 5. } & \text { Mkpunator } \\
\end{array}$ & $\begin{array}{l}\text { Water borehole } \\
\text { Electricity } \\
\text { Health centre } \\
\text { Electricity } \\
\text { Electricity }\end{array}$ & $\begin{array}{l}\text { Submassible pump problem. } \\
\text { Cables stolen. } \\
\text { Lack of essential drugs. } \\
\text { Has not worked at all. } \\
\text { Transformer packed up }\end{array}$ \\
\hline Nsukka & $\begin{array}{ll}\text { 1. } & \text { Ajuna Obimo } \\
\text { 2. } & \text { Agbaemere } \\
\text { 3. } & \text { Okutu } \\
\text { 4. } & \text { Alor Uno } \\
\text { 5. } & \text { Obigeobukpa } \\
\end{array}$ & $\begin{array}{l}\text { Road Rehabilitation water } \\
\text { borehole } \\
\text { Health centre } \\
\text { Water borehole } \\
\text { Water borehole }\end{array}$ & $\begin{array}{l}\text { Very bad. } \\
\text { Overhead tank rusty inside Inadequate } \\
\text { drugs } \\
\text { Submassible pump problem } \\
\text { Submassible pump problem }\end{array}$ \\
\hline Isi-uzo & $\begin{array}{ll}1 . & \text { Mbu } \\
\text { 2. } & \text { Umuaram } \\
\text { 3. } & \text { Neke } \\
\text { 4. } & \text { Aguamede }\end{array}$ & $\begin{array}{l}\text { Electricity } \\
\text { Electricity } \\
\text { Health Centre } \\
\text { Road rehabilitation }\end{array}$ & $\begin{array}{l}\text { Transformer faulty } \\
\text { Lightening arrestor destroyed } \\
\text { Lack of adequate drugs } \\
\text { Very bad. }\end{array}$ \\
\hline
\end{tabular}

Source: Field work 2012.

As stated in the methodology, questionnaires were distributed to sampled communities as well as to CSDP officials to ascertain their views on issues connected with the performance of LEEMP projects. The responses to the questions are as presented in table 4.

Table 4

Responses: numbers and percentages

\begin{tabular}{|c|c|c|c|c|c|c|c|c|c|c|c|}
\hline $\begin{array}{l}\mathbf{S} / \\
\mathbf{N}\end{array}$ & STATEMENTS & $\begin{array}{l}\mathbf{S} \\
\mathbf{A}\end{array}$ & $\%$ & $\mathbf{A}$ & $\%$ & D & $\%$ & SD & $\%$ & $\mathbf{U}$ & $\%$ \\
\hline 1 & LEEMP projects are serving your community very well & - & - & 50 & $\begin{array}{l}13 . \\
89\end{array}$ & $\begin{array}{l}10 \\
0\end{array}$ & $\begin{array}{ll}27 . \\
78\end{array}$ & $\begin{array}{l}17 \\
0\end{array}$ & $\begin{array}{l}47.2 \\
2\end{array}$ & $\begin{array}{l}4 \\
0\end{array}$ & 11.11 \\
\hline 2 & $\begin{array}{l}\text { The present state of the projects is a result of poor follow } \\
\text { up funding and monitoring by development partners. }\end{array}$ & $\begin{array}{l}22 \\
0\end{array}$ & $\begin{array}{ll}61 . \\
11\end{array}$ & 80 & $\begin{array}{l}22 . \\
22\end{array}$ & 55 & $\begin{array}{l}15 . \\
28\end{array}$ & - & - & $\begin{array}{l}4 \\
5\end{array}$ & 12.5 \\
\hline 3 & $\begin{array}{l}\text { There were local conflicts/politics over chieftaincy } \\
\text { matters, town unions etc in your town during the } \\
\text { projects }\end{array}$ & $\begin{array}{l}12 \\
5\end{array}$ & $\begin{array}{l}34 . \\
72\end{array}$ & $\begin{array}{l}13 \\
5\end{array}$ & $\begin{array}{l}37 . \\
50\end{array}$ & 30 & $\begin{array}{l}8.3 \\
3\end{array}$ & 10 & 2.78 & $\begin{array}{l}6 \\
\mathbf{0}\end{array}$ & 16.67 \\
\hline 4 & $\begin{array}{l}\text { The conflicts were settled satisfactorily before the } \\
\text { commencement/completion of the projects }\end{array}$ & 5 & $\begin{array}{l}1.3 \\
9\end{array}$ & 30 & $\begin{array}{l}8.3 \\
3\end{array}$ & $\begin{array}{l}10 \\
5\end{array}$ & $\begin{array}{l}29 . \\
17\end{array}$ & $\begin{array}{l}17 \\
0\end{array}$ & $\begin{array}{l}47.2 \\
2\end{array}$ & $\begin{array}{l}0 \\
\mathbf{0}\end{array}$ & 16.67 \\
\hline 5 & $\begin{array}{l}\text { There were disagreements among interests/villages in } \\
\text { your community concerning the siting of the projects. }\end{array}$ & $\begin{array}{l}14 \\
5\end{array}$ & $\begin{array}{ll}40 . \\
28\end{array}$ & $\begin{array}{l}20 \\
\mathbf{0}\end{array}$ & 55. & - & - & - & - & 1 & 14.17 \\
\hline 6 & $\begin{array}{l}\text { The members of your community answer calls for } \\
\text { maintaining the projects. }\end{array}$ & 40 & 11. & 25 & $\begin{array}{ll}6.9 \\
4 \\
\end{array}$ & $\begin{array}{ll}16 \\
5\end{array}$ & $\begin{array}{l}45 . \\
83\end{array}$ & $\begin{array}{ll}13 \\
0\end{array}$ & $\begin{array}{ll}36.1 \\
1\end{array}$ & - & - \\
\hline 7 & $\begin{array}{l}\text { The local government has been supportive in the } \\
\text { maintenance of the projects after completion. }\end{array}$ & - & - & 10 & $\begin{array}{l}2.7 \\
8\end{array}$ & $\begin{array}{ll}18 \\
0\end{array}$ & $\mathbf{5 0}$ & $\begin{array}{l}14 \\
5\end{array}$ & $\begin{array}{l}40.2 \\
8\end{array}$ & $\begin{array}{l}2 \\
5\end{array}$ & 6.94 \\
\hline 8 & $\begin{array}{l}\text { Rich members of your community especially abroad } \\
\text { members support the projects with their } \\
\text { resources/connections. }\end{array}$ & 35 & $\begin{array}{l}9.7 \\
2\end{array}$ & 50 & $\begin{array}{l}13 . \\
89\end{array}$ & $\begin{array}{l}13 \\
0\end{array}$ & $\begin{array}{ll}36 . \\
11\end{array}$ & 70 & $\begin{array}{l}19.4 \\
4\end{array}$ & $\begin{array}{l}1 \\
5\end{array}$ & 4.17 \\
\hline 9 & $\begin{array}{l}\text { The LEEMP project(s) is really the most pressing need } \\
\text { of your community. }\end{array}$ & $\begin{array}{ll}10 \\
0\end{array}$ & 27. & $\begin{array}{ll}15 \\
0\end{array}$ & $\begin{array}{ll}41 . \\
7\end{array}$ & 70 & $\begin{array}{ll}19 . \\
4\end{array}$ & 45 & 12.5 & $\begin{array}{l}3 \\
5\end{array}$ & 9.7 \\
\hline 10 & $\begin{array}{l}\text { Your community leaders/representatives were involved } \\
\text { in the choice of the LEEMP projects and their locations. }\end{array}$ & $\begin{array}{l}15 \\
5\end{array}$ & $\begin{array}{l}43 . \\
1\end{array}$ & $\begin{array}{l}20 \\
5\end{array}$ & 57 & 50 & $\begin{array}{l}13 . \\
89\end{array}$ & - & - & $\begin{array}{l}\mathbf{1} \\
\mathbf{0}\end{array}$ & 2.78 \\
\hline 11 & $\begin{array}{l}\text { Your community leaders/representatives were involved } \\
\text { in the implementation of LEEMP projects. }\end{array}$ & $\begin{array}{ll}12 \\
0\end{array}$ & 33. & $\begin{array}{ll}17 \\
5\end{array}$ & $\begin{array}{l}48 . \\
6\end{array}$ & 45 & $\begin{array}{ll}12 . \\
5\end{array}$ & 20 & 5.56 & $\begin{array}{l}3 \\
\mathbf{0}\end{array}$ & 8.33 \\
\hline 12 & $\begin{array}{l}\text { If your answer to (11) is in the affirmative, the } \\
\text { community was involved in: } \\
\text { Raising fund } \\
\text { Providing labour } \\
\text { Providing material resources }\end{array}$ & $\begin{array}{l}18 \\
0 \\
25 \\
0 \\
16 \\
0\end{array}$ & $\begin{array}{l}50 \\
69 . \\
4 \\
44 . \\
4\end{array}$ & $\begin{array}{l}22 \\
0 \\
15 \\
0 \\
13 \\
5\end{array}$ & $\begin{array}{l}61 . \\
1 \\
41 \\
7 \\
37 \\
5\end{array}$ & $\begin{array}{l}- \\
- \\
65\end{array}$ & $\begin{array}{l}- \\
- \\
18 . \\
1\end{array}$ & $\begin{array}{l}- \\
- \\
-\end{array}$ & & $\begin{array}{l}- \\
- \\
4 \\
0\end{array}$ & 11.11 \\
\hline 13 & $\begin{array}{l}\text { The local government supported the maintenance of } \\
\text { your LEEMP project through financial contributions. }\end{array}$ & - & - & $\begin{array}{ll}10 \\
0\end{array}$ & 27. & $\begin{array}{ll}20 \\
\mathbf{0}\end{array}$ & 55. & 75 & 20.8 & $\begin{array}{l}2 \\
5\end{array}$ & 7.0 \\
\hline & B & LE & $\overline{\mathbf{A P}(\mathbf{C}}$ & P) & EST & NN & & & & & \\
\hline 14 & $\begin{array}{l}\text { LEEMP projects completed few years ago have not } \\
\text { been functioning well. }\end{array}$ & - & - & 9 & $\begin{array}{ll}22 . \\
5\end{array}$ & 31 & $\begin{array}{ll}70 . \\
5\end{array}$ & - & - & - & - \\
\hline 15 & There has been follow up funding procedure for & 10 & 25 & 15 & 37. & 5 & 12. & - & - & 1 & 25 \\
\hline
\end{tabular}




\begin{tabular}{|c|l|l|l|l|l|l|l|l|l|l|l|}
\hline & maintaining LEEMP projects & & & & $\mathbf{5}$ & & $\mathbf{5}$ & & $\mathbf{0}$ & \\
\hline $\mathbf{1 6}$ & $\begin{array}{l}\text { The procedures are diligently followed in administering } \\
\text { LEEMP projects in the state. }\end{array}$ & $\mathbf{2 0}$ & $\mathbf{5 0}$ & $\mathbf{1 5}$ & $\mathbf{3 7 .}$ & - & - & - & - & $\mathbf{5}$ & $\mathbf{1 2 . 5}$ \\
\hline $\mathbf{1 7}$ & $\begin{array}{l}\text { Local politics/conflicts over chieftaincy matters, town } \\
\text { unions, land disputes impinge on th sustainability of } \\
\text { LEEMP projects. }\end{array}$ & $\mathbf{2 4}$ & $\mathbf{6 0}$ & $\mathbf{1 0}$ & $\mathbf{2 5}$ & $\mathbf{6}$ & $\mathbf{1 5}$ & - & - & - & - \\
$\mathbf{1 8}$ & $\begin{array}{l}\text { Disagreements among community members over the } \\
\text { siting of LEEMP projects affect its sustainability } \\
\text { negatively }\end{array}$ & $\mathbf{2 7}$ & $\begin{array}{l}\mathbf{6 7} \\
\mathbf{5}\end{array}$ & $\mathbf{1 3}$ & $\mathbf{3 2 .}$ & - & - & - & - & - & - \\
\hline $\mathbf{1 9}$ & $\begin{array}{l}\text { Local governments are very supportive in sustaining } \\
\text { LEEMP projects in their areas. }\end{array}$ & $\mathbf{2 5}$ & $\mathbf{6 2 .}$ & $\mathbf{1 0}$ & $\mathbf{2 5}$ & $\mathbf{5}$ & $\mathbf{1 2 .}$ & - & - & - & - \\
\hline $\mathbf{2 0}$ & $\begin{array}{l}\text { Apathy and unwillingness of the influential/rich } \\
\text { members of the communities affect LEEMP projects } \\
\text { negatively }\end{array}$ & $\mathbf{3 0}$ & $\mathbf{7 5}$ & $\mathbf{1 0}$ & $\mathbf{2 5}$ & - & - & - & - & - & - \\
\hline
\end{tabular}

Source: Field survey.

A perusal of the opinions of respondents on issues that affected the sustainability of LEEMP projects as contained in table 4 shows that the opinions of the community members were in consonance with that of LEEMP/CSDP on many of the issues. For instance, they both agree that conflicts constituted impediments to sustainability of LEEMP projects, (72.22 percent and 85 percent respectively). In the same vein, there was agreement with respect to the politics of location ( 95.84 percent and 100 percent) and poor follow-up funding for maintenance of projects ( 83.33 percent and 87.5 percent) respectively. Though LEEMP/CSDP respondents were of the opinion that follow-up funding for maintenance procedures were diligently applied, the result on ground negates the claim.

Table 5

\section{Hypotheses testing using chi-square}

\begin{tabular}{|l|l|l|l|l|l|}
\hline $\mathbf{S} / \mathbf{n}$ & Hypotheses & $\begin{array}{l}\text { Cal } \\
\text { Val }\end{array}$ & $\begin{array}{l}\text { Tab } \\
\text { Val }\end{array}$ & $\begin{array}{l}\text { Level of } \\
\text { sign\% }\end{array}$ & $\begin{array}{l}\text { Decision: Reject null hypotheses if } \\
\mathbf{X}^{\mathbf{2}} \mathbf{C a l}>\mathbf{X}^{\mathbf{2}} \mathbf{T a b}\end{array}$ \\
\hline $\mathbf{1}$ & $\begin{array}{l}\text { Follow up funding did not negatively affect } \\
\text { the sustainability of LEEMP projects in } \\
\text { Enugu State }\end{array}$ & 17.79 & 15.51 & 0.05 & Null hypothesis rejected \\
\hline $\mathbf{2}$ & $\begin{array}{l}\text { Local politics/conflicts had no negative effect } \\
\text { on the sustainability of LEEMP projects in } \\
\text { Enugu state }\end{array}$ & 21.53 & 15.51 & 0.05 & Null hypothesis rejected \\
\hline $\mathbf{3}$ & $\begin{array}{l}\text { Siting/location of LEEMP projects did not } \\
\text { impinge on their sustainability in Enugu State }\end{array}$ & 57.25 & 15.51 & 0.05 & Null hypothesis rejected \\
\hline $\mathbf{4}$ & $\begin{array}{l}\text { Lack of political will by indigenes did not } \\
\text { constitute impediment to the sustainability of } \\
\text { LEEMP projects }\end{array}$ & 141.69 & 15.51 & 0.05 & Null hypothesis rejected \\
\hline
\end{tabular}

The Chi-square tests of the hypotheses and the values as presented in table 5 above resulted in the rejection of all the null hypotheses proposed in the work This is in line with the decision rule that when the calculated value of chi square is greater than the tabulated value, the null hypotheses should be rejected. The calculated values of chi squares in the four hypotheses tested are greater than the tabulated values. This implies that poor follow-up funding; local politics and conflicts; inappropriate location and lack of political will by indigenes, are the major factors that contributed to the non-sustainability of LEEMP projects in Enugu State.

\section{Recommendations}

Based on the findings of this study, the following recommendations are made. Development partners should not leave the projects just after handover to the communities. They should to monitor the progress of the projects for at least ten years. In view of the low financial capability of many Nigerian communities, fund for project maintenance for ten years post delivery period should be built into project costing by the development partners. This is because the presence of the development partner(s) in the communities is a unifying tonic (Baccus, 2008). There need to be a department in the development partners' organizations charged with the oversight function of reaching out to former beneficiaries of their interventions, thus, encouraging and organizing them to have avenues for meeting to share experiences on the challenges facing their projects

Local politics constitute the bane of community progress. It is capable of frustrating the goals of the projects and should therefore be unveiled on time and resolved before project take off. Development partners should have the policy not to intervene in communities where there are conflicts. This can help enthrone peace because the communities need these interventions. Proper education of the stakeholders and opinion leaders on the need for peace in the communities to enhance the success of the projects should be emphasized. Development partners can meet with these people (stakeholders) from time to time to nip any conflict in the bud.

The siting of projects need to be where the greatest number of the people can access them. Any site that generates controversy among the people should not be used. The development partners need to include the 
criteria for selecting a site in their plan so as to avoid easy manipulations. Through proper orientation, the powerful interests in the communities can be taught to be more selfless in their service to their communities.

Finally, local governments should be compelled through state enactment to make cash contributions towards LEEMP projects. The practice where the communities contribute 20 percent of the project cost without any cash commitment from the local governments leaves much to be desired. . In fact, local governments should equally contribute 20 percent of the project cost. This will make them pick more interest in the projects and in participating in the overseeing functions to enhance project sustainability. Above all, rich/influential members of the community should realize that they have no other place than their communities and therefore, be partners in progress. Development partners even before releasing funds should demand the contacts of the big shots in the communities to bring them into the project. They should work closely with other elites at home to carry all the stakeholders along.

\section{Conclusion}

The reason for the massive failure of LEEMP projects in Enugu state is because development partners fail to look inward to identify and address the peculiarities of the problems of the communities before investing there. If development partners and governments continue to overlook the place of follow-up funding, local politics/conflicts, politics of siting and apathy of the local governments as well as the few rich people in the community in the sustainability or otherwise of development projects, much resources will continue to be committed on development efforts without commensurate results. Members of the community have to be on the driver's seat of their own development but the issues that pit them one against the other need to be resolved before placing them on the driving seat to avoid a preventable crash

\section{References}

[1]. Adato, M; Besley, T. Haddad, L and Hoddinott, J., 1999. "Participation and poverty reduction: Issues, theory and new evidence from South Africa”. Background paper for World Bank Development Report 2000/2001. International Food Policy Research Institute and World Bank. Washington, D.C.

[2]. Anna, M. and Diana, M, 2007. "Securing inclusion: Strategies for community empowerment and state redistribution", Environment and Urbanization, 19(2): 425-439.

[3]. Baccus,I; Hemson, D; Hicks, J. and Piper, L. 2008. "Community development and engagement with local governance in South Africa", Community Development Journal 43(3): 297-311.

[4]. Diana M, and Satterthwaite, D. 2007,. "Strategies for grassroots control of international aid", Environment and Urbanization, 19(2); 483-500.

[5]. European Commission, 2006. "Sustainability of international cooperation projects in the field of higher education and training," Handbook on sustainability. Luxembourg: Office for Official Publications of the European Communities.

[6]. Eze, G.O. 2007. "The politics of poverty eradication in Nigeria", Journal of Policy and Development Studies, 2 (3): 16-17.

[7]. Ibeawuchi, E.I and Nwachukwu, C.C., 2010. "An investigation on the impact of FADAMA II Project implementation in Imo State", American Journal of Scientific and Industrial Research, 1(3): 532-538.

[8]. International Development Association, 2009. "Community - Driven Development: Delivering the results people need", IDA at Work. (http://www.worldbank.org/ida(12/06/2012).

[9]. International Federation for Agricultural Development, 2010a. IFAD Strategy for rural poverty reduction in Asia and the Pacific. Rome.

[10]. IFAD, 2011b, IFAD Strategic Framework 2007-2010. Rome.

[11]. IFAD, 2007., IFAD's Approach to sustainability: Draft of the presentation subsequently made by ShyamKhadka to the third Session of the consultation on the Eighth Replenishment of IFAD's Resources, 8-0 July, Rome.www.ifad.org/gbdocs/repl/8/iiie/presentations/sustainability.pdf.

[12]. Khan, M.A. 2000, "Planning for monitoring of project sustainability: A Guideline on concept, issues and tools; M and E News, file://D:/Khan.htm(12/06/2012).

[13]. LEEMP, 2005, Monitoring Reports and Financial Records, June.

[14]. LEEMP, 2009, "Project impact evaluation of the Local Empowerment and Environmental Management Project (LEEMP)". Federal Ministry of Environment, Asokoro Abuja.

[15]. LEEMP, Enugu 2007,. Annual Report.

[16]. LEEMP, Enugu 2008,. Annual Report.

[17]. LEEMP, 2004,. "Community Driven Development Strategy: Tool for poverty reduction". Emerging lessons from Local Empowerment and Environmental Management Project (LEEMP), Abuja

[18]. Olukotun, G.A., 2008. “Achieving project sustainability through community participation", Journal of the Social sciences, 17(1): 2129.

[19]. Onakuse, S. and Eamon, L., 2007, "Policies, programmes, and sustainable development in Nigeria: A critique", Africana, 1(1): 4144.

[20]. Owoh, G.C., 2008. "Benefits of participatory monitoring and challenges in CDD”, Enugu LEEMP News, 3(1): 28-29.

[21]. Sara, L. and Katz, T. 1997., "Making rural water sustainable: Report on the impact of project rules", United Nations Development Programme and World Bank Water and Sanitation Programme, Washington, D.C.

[22]. Teodora, J.I. and Rayosco, J.C., 2009. "Community-driven land tenure Strategies: The experiences of the Homeless People's Federation of the Philippines", Environment and Urbanization, 21(2): 415-441.

[23]. Ugwoke, J.O., 2008. "Enugu State LEEMP: The journey so for”, Enugu LEEMP News, $3(1)$ : 13-14.

[24]. World Bank, 2003. "Community - Driven Development: A study methodology", Operation Evaluation Department, Washington D.C.

[25]. World Bank, 2005. "Harmonization of tools and approaches of CDD projects in Nigeria (CPRP, FDAMA II and LEEMP)", Main Report (Draft), Document of the World Bank Nigeria. 